\title{
Identification of meat-isolated Enterobacteriaceae by an In silico-ARDRA approach
}

\author{
A. Messaoudi ${ }^{*}$ and F. Wagenlehner ${ }^{2}$ \\ ${ }^{1}$ Laboratoire Microorganismes et Biomolécules Actives, Département de Biologie, Faculté \\ des Sciences de Tunis, Campus Universitaire, 2092 Tunis, Tunisie; ${ }^{2}$ Department of Urology, \\ Pediatric Urology and Andrology, Justus-Liebig-University, Giessen, Germany
}

\begin{abstract}
A collection of 20 complete and published sequences were obtained from the NCBI Genbank. Then, an «electronic PCR » was realised for the sequences using the universal primer set S-D-Bact-0008-a-S-20 and S-D-Bact-1495-a-A-20 which target the conserved regions of the $16 \mathrm{~S}$ ribosomal DNA gene. The In silico enzymatic restriction of amplified products by 180 restriction enzymes allowed the selection of AluI, MspI, and RsaI as the most discriminative restriction enzymes. Sixty isolates were collected from 10 different meat samples (chicken, turkey hen, sheep, pig, dromedary, cow, horse, fish, and ostrich). Preliminary morphological identification delimited the range of the concerned genera. Thus, the studied strains were assigned to one of the following genera: Klebsiella, Enterobacter, Salmonella, Proteus, Escherichia, Yesinia and Shigella spp. Enzymatic restriction of the 16S rDNA gene of the isolated strains using the same enzymes chosen for the theoretical restriction gave 12 ARDRA groups. Comparison of theoretical and experimental ARDRA profiles, using length and number analyses of the restricted fragments, confirm and identify each strain at the genus level, and sometimes up to species level. Epidemiological investigations can optimally be performed by the ARDRA technique, employing restriction enzymes designed electronically through public databases.
\end{abstract}

Keywords: 16 rDNA, ARDRA, Enterobacteriaceae.

Abbreviations: ARDRA - Amplified Ribosmal DNA Restriction Analysis; rDNA - ribosomal Deoxyribonucleic acid; mM - millimolar; PCR - Polymerase Chain Reaction; tpm - Tour per minute; $\mu \mathrm{l}$ - Microliter; $\mathrm{h}$ - Hour; M - Molar; TE - Tris-EDTA; min - Minute; Tris Trihydroxymethyl aminomethane; EDTA - Ethylenediaminetetraacetic acid.

$$
\text { تحديد هوية الباكتيريا المتواجدة فى اللحوم باستخدام طريقة التقطيع الانزيمي الاكترونية }
$$$$
\text { مختبر الاحياء الدقيقة، قسم البيولوجيا، كلية العلوم بتونس ، المركب الجامعي } 2092 \text { تونس ، الجمهورية التونسية. }
$$$$
\text { قسم جراحة المسالك البولية ، جراحة المسالك البولية لاى الاطفال والذكورة ، جامعة جيسوس ليبج - غيسن ، المانيا. }
$$

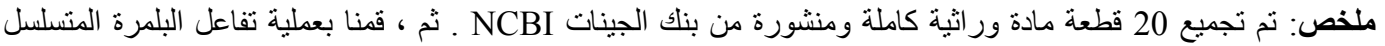

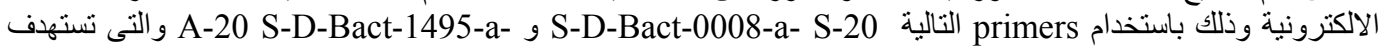

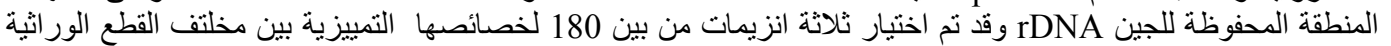

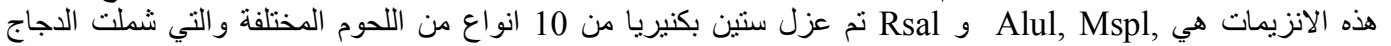

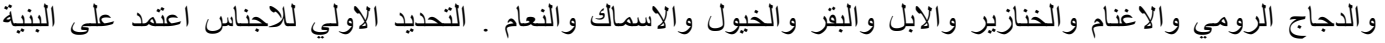

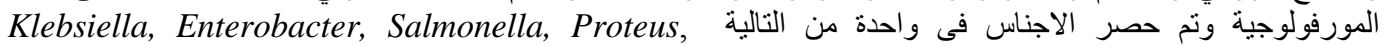
Escherichia, Yesinia and Shigella spp.

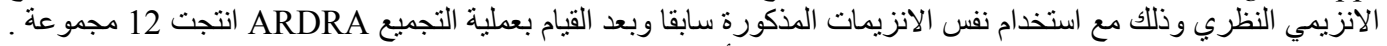

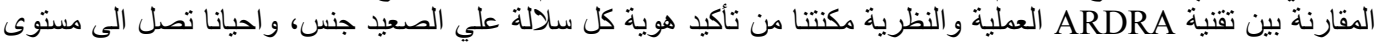

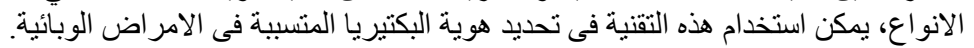

\footnotetext{
${ }^{*}$ Corresponding Author, Email: messaoudiabdelmonemster@gmail.com
} 


\section{Introduction}

The Enterobacteriaceae are Gramnegative bacteria, most of which are mobile with polar flagella, they grow easily on the usual media in $24 \mathrm{~h}$ at $37^{\circ} \mathrm{C}$ aerobically and anaerobically, their nutritional requirements are generally reduced, most of them multiply in synthetic medium with a simple carbon source like glucose (Brenner, 1980). On the biochemical species of this family are generally oxidase negative, reduced nitrate to nitrite with the exception of some species of Erwinia and Yersinia. The name of Enterobacteriaceae was given because these bacteria are usually normal or pathological host, following the microbial species of digestive tract of humans and animals (Williams, 1965).

Many members of this family are a normal part of the microbial community found in the intestines of humans and other animals (Hormaeche and Edwards, 1960), while others are found in water or soil, or are parasites on a variety of different animals and plants. E. coli, is one of the most important model organisms, and its genetics and biochemistry have been closely studied.

The accurate identification of Enterobacteriaceae and other glucosefermenting and nonfermenting gramnegative bacilli has been the subject of many hundreds of publications over the years (O'Hara et al., 1965). The use of commercial kits, either manual or automated, to identify these organisms is common practice. Some species are difficult to identify with phenotypic and biochemical identification schemes commonly used outside reference laboratories. $16 \mathrm{~S}$ ribosomal DNA (rDNA)-based identification of bacteria potentially offers a useful alternative when phenotypic and biochemical characterization methods fail (Michel et al., 2000).

The aim of this study was to identify environmental isolated strains (meat) by an In Silico-ARDRA (amplified rDNA restriction analysis) approach.

\section{Material and methods}

\section{Sample collection and preparation}

Food samples $(n=15)$, including ground beef, packed pork sausage, retail packages of beef steak, pork chops, hamburger, fish and products from turkey and chicken origin, were randomly collected from retail stores of five supermarket chains in Tunis and from naturally-raised animals (at a farm in SidiThabet, Tunis, Tunisia) (Table 2) (Messaoudi et al., 2009). Sampling visits were made one day per week for 6 months (September 2005 to February 2006). Eight prepackaged raw meat products (two of each meat type) were randomly selected and transported on ice to the laboratory. Each sample was aseptically removed and placed in a plastic bag that contained 200 to $500 \mathrm{ml}$ of buffered peptone (Difco Laboratories, Detroit, Mich.), depending on the sample size. The bag was shaken manually for $3 \mathrm{~min}$ and left on ice for 20 $\min$.

The collected meat samples were analyzed as follows: $11 \mathrm{~g}$ of each sample was suspended in sterile peptone and then selenite broth at $37^{\circ} \mathrm{C}$ for $24 \mathrm{~h}$. According to the standard dilution method, $1 \mathrm{ml}$ from each concentration was plated onto Hektoen and MacConkey agar plates and incubated at $37^{\circ} \mathrm{C}$ for $24 \mathrm{~h}$ (Nataro et Kaper, 1998) (Le Minor, 1986). Colonies suspected to resemble Enterobacter and Klebsiella spp. (on the basis of colony size and morphology) were selected for identification and further studies.

\section{Morphological characterization of isolates}

\section{Culture on Hektoen agar media}

Hektoen is a selective and differential agar primarily used to recover Salmonella and Shigella from patient 
specimens. Hektoen contains indicators of lactose fermentation and $\mathrm{H}_{2} \mathrm{~S}$ production; as well as inhibitors to prevent the growth of Gram-positive bacteria. The pattern of lactose fermentation and $\mathrm{H}_{2} \mathrm{~S}$ production aids in the organism identification. Table (1) summarizes the different types of colonies observed on Hektoen medium (Nataro et Kaper, 1998).

Table 1. Colonies observed on the Hektoen agar media.

\begin{tabular}{llll}
\hline $\begin{array}{l}\text { Colonies with } \\
\text { Salmon color }\end{array}$ & $\begin{array}{l}\text { Colonies with Salmon color } \\
\text { and black center }\end{array}$ & $\begin{array}{l}\text { Colonies blue-green } \\
\text { with black center }\end{array}$ & $\begin{array}{l}\text { Colonies blue-green } \\
\text { or green }\end{array}$ \\
\hline Escherichia & $\begin{array}{l}\text { Citrobacter } \\
\text { Levinea }\end{array}$ & Salmonella & Shigella ou \\
Citrobacter & & & Salmonella \\
Klebsiella & & & \\
Enterobacter & & & \\
Serratia & & & \\
Yersinia & & & \\
\hline
\end{tabular}

Table 2. Origin of strain.

\begin{tabular}{lll}
\hline Meat type & Origin & Number of isolates \\
\hline Lamb's meat & Reared animals & $\mathbf{1}$ \\
Meat of ostrich & Carrefour* & $\mathbf{1}$ \\
Meat of turkey & Mliha* & $\mathbf{1}$ \\
Sausage of Frankfort & Mazreaa* & $\mathbf{3}$ \\
Chicken & Mliha* & $\mathbf{3}$ \\
Chicken & Mazreaa* & $\mathbf{4}$ \\
Scallop of turkey & Mazreaa* & $\mathbf{5}$ \\
Chicken & Pinda* & $\mathbf{2}$ \\
Meat of turkey & Carrefour* & $\mathbf{4}$ \\
Meat of pigs & Carrefour* & $\mathbf{3}$ \\
Meat of dromedary & Carrefour* & $\mathbf{3}$ \\
Sheep & Reared animals & $\mathbf{2}$ \\
Fish & Sea bream & $\mathbf{0}$ \\
\hline
\end{tabular}

(*) Meat supermarket

\section{Culture on Mac-Conkey agar media} MacConkey (also McConkey) agar is a culture medium designed to grow Gram-negative bacteria and stain them for lactose fermentation. By utilizing the lactose available in the medium, lactose fermenting bacteria such as E. coli, Enterobacter and Klebsiella spp. will produce acid, which lowers the $\mathrm{pH}$ of the agar below 6.8 and results in the appearance of red/pink colonies. Nonlactose fermenting bacteria such as Salmonella, Proteus and Shigella spp. cannot metabolize lactose, and will use peptone instead. This forms ammonia, which raises the $\mathrm{pH}$ of the agar, and leads to the formation of white/colorless colonies (Le Minor, 1986).

\section{Chromosomal DNA extraction}

Chromosomal DNA extraction was carried out as described by Chen and Kuo (1993) and Birnboim and Doly (1979). After an overnight culture at $37^{\circ} \mathrm{C}$ on MacConkey agar medium, colonies were suspended in $1.5 \mathrm{ml}$ of Luria broth 
medium (Difco Laboratories, Detroit, Mich) and incubated at $37^{\circ} \mathrm{C}$ for $24 \mathrm{~h}$. The broth was then centrifuged $(12,000 \mathrm{tpm}$ during $3 \mathrm{~min}$ at $4^{\circ} \mathrm{C}$ ) and the supernatant suspended into $200 \mu \mathrm{l}$ of extraction buffer (Tris acetate $[\mathrm{pH} 7.8] ; 40 \mathrm{mM}$, sodium acetate; $20 \mathrm{mM}$, EDTA [pH 8]; $1 \mathrm{mM}$ and SDS $1 \%$ ). The cell detritus were removed by adding $66 \quad \mu l \quad \mathrm{NaCl} \quad 5 \quad \mathrm{M}$ and centrifugation at $12,000 \mathrm{tpm}$ for $10 \mathrm{~min}$ at $4^{\circ} \mathrm{C}$. The supernatant was removed and was then treated with an equal volume of phenol-chloroform (1:1). The aqueous phase was discarded by 2.5 volume of chilled absolute ethyl alcohol and two washings in ethyl alcohol $70 \%(\mathrm{v} / \mathrm{v})$. DNA was purified by TE ((Tris- $\mathrm{HCl}[\mathrm{pH}$ 7.4]; $10 \mathrm{mM}$, EDTA [pH 8]; $1 \mathrm{mM}$ ) and stored at $-20^{\circ} \mathrm{C}$.
Amplification of 16S rDNA gene

Amplification of $16 \mathrm{~S}$ rDNA gene was carried out with universal primers $\mathrm{S}$ D-Bact-0008-a-S-20 and S-D-Bact1495-a-S-20 (Wheeler et al., 1996) (Figure 2). Each reaction tube contained $0.5 \mu \mathrm{M}$ of each primer, $50 \mathrm{mM}$ Tris- $\mathrm{HCl}$ (pH 9.0), $50 \mathrm{mM} \mathrm{KCl}, 7 \mathrm{mM} \mathrm{MgCl} 2,2 \mu \mathrm{l}$ of purified DNA, $100 \mathrm{mM}$ deoxynucleoside triphosphate, and $0.5 \mathrm{U}$ of Taq polymerase (Applied Biosystems, Milano, Italy) and was adjusted to a total volume of $50 \mu \mathrm{l}$. Samples were amplified in a Biomed model 60 thermal cycler (Bio-Rad, Hercules, CA) programmed for a first cycle of denaturation $(10 \mathrm{~min}$ at $\left.94^{\circ} \mathrm{C}\right)$.

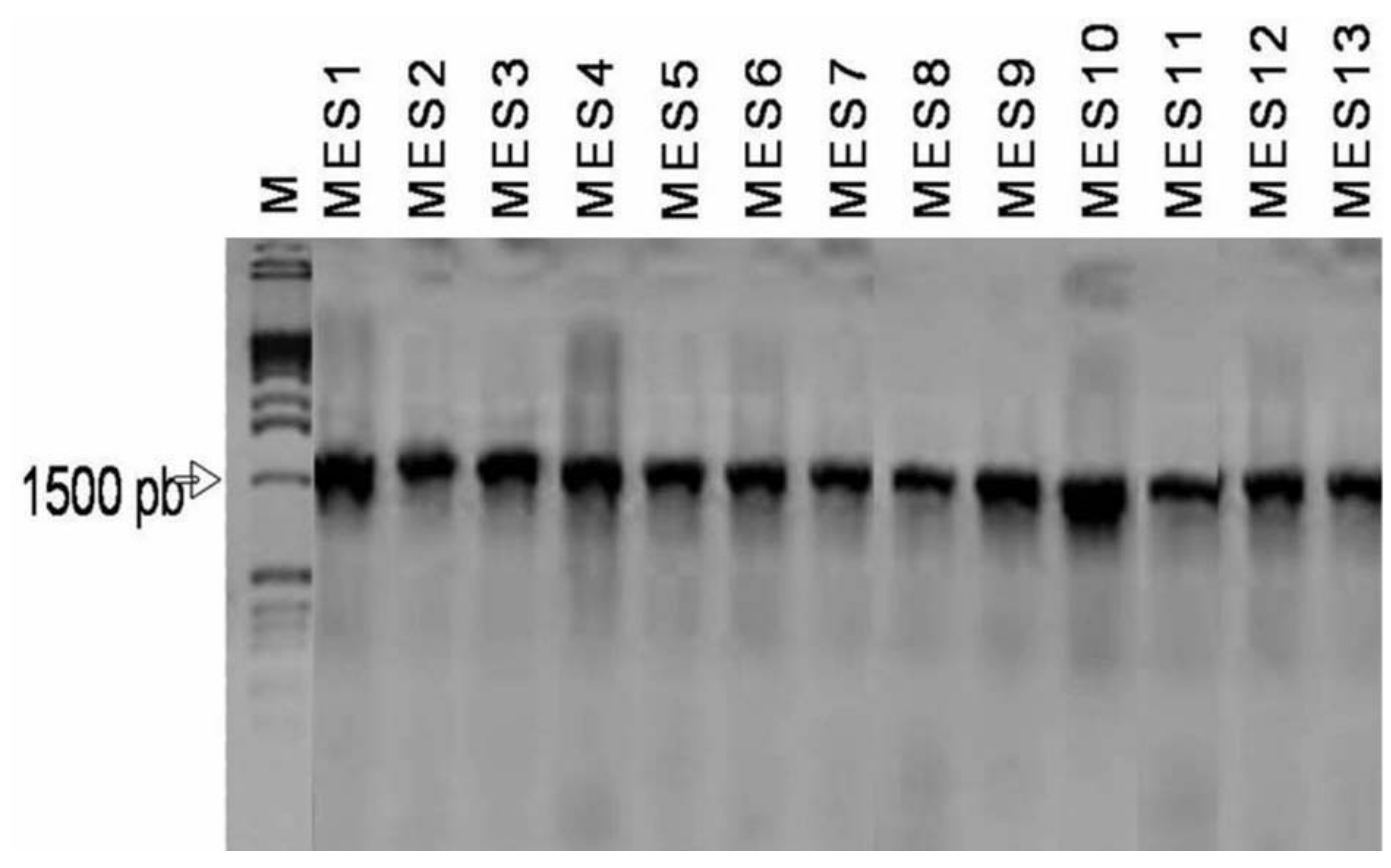

Figure 2. Amplification of rDNA $16 \mathrm{~S}$ gene by polymerase chain reaction and resolved on $1,5 \%$ polyacrylamide gel. $M$ denote the 1 bk DNA ladder.

The 35 subsequent cycles of amplification consisted of denaturation for $1 \mathrm{~min}$ at $94^{\circ} \mathrm{C}$, annealing for $1 \mathrm{~min}$ at $40^{\circ} \mathrm{C}$, and extension for $1 \mathrm{~min}$ at $72^{\circ} \mathrm{C}$, with a final extension step of $10 \mathrm{~min}$ at $72^{\circ} \mathrm{C}$. The products were electrophoresed on a $1.5 \%$ agarose gel and viewed by ethidium bromide staining.

\section{Enzymatic restriction of $16 \mathrm{~S}$ rDNA}

ARDRA is a restriction fragment length polymorphism pattern of polymerase chain reaction amplified $16 \mathrm{~S}$ rDNA gene (Heyndrickx et al., 1996). We applied ARDRA to rDNA 16S gene of isolated strains using RsaI, AluI, and MspI enzymes. The final reaction was carried out in a final volume of $10 \mu 1$. $16 \mathrm{~S}$ rDNA 
products were digested in an overnight mixture reaction in the presence of $1 \mu l$ of the appropriate buffer, $1 \mu$ l of the amplified DNA and $8 \mu \mathrm{l}$ of restriction enzymes (5-10 U / $\mu \mathrm{l})$ : AluI, MspI and RsaI, and resolved on $6 \%$ polyacrylamide gel (Difco Laboratories, Detroit, Mich) (Figure 3a, 4a and 5a).

\section{Data analysis}

\section{GenBank database}

We searched the sequences of $16 \mathrm{~S}$ rDNA of different species of Enterobacteriaceae studied in the genomic bank: GenBank (www.ncbi.nlm.nih.gov) (Dennis et al., 2008).

\section{DNAMAN}

DNAMAN is a one-for-all software package for molecular biology applications. This package provides an integrated system with versatile functions for high efficiency sequence analysis. DNAMAN carries out all these tasks: restriction analyses, multiple sequence alignment, designing PCR primers, protein sequence analysis and drawing plasmids (http://www.lynnon $. \operatorname{com} /)$.
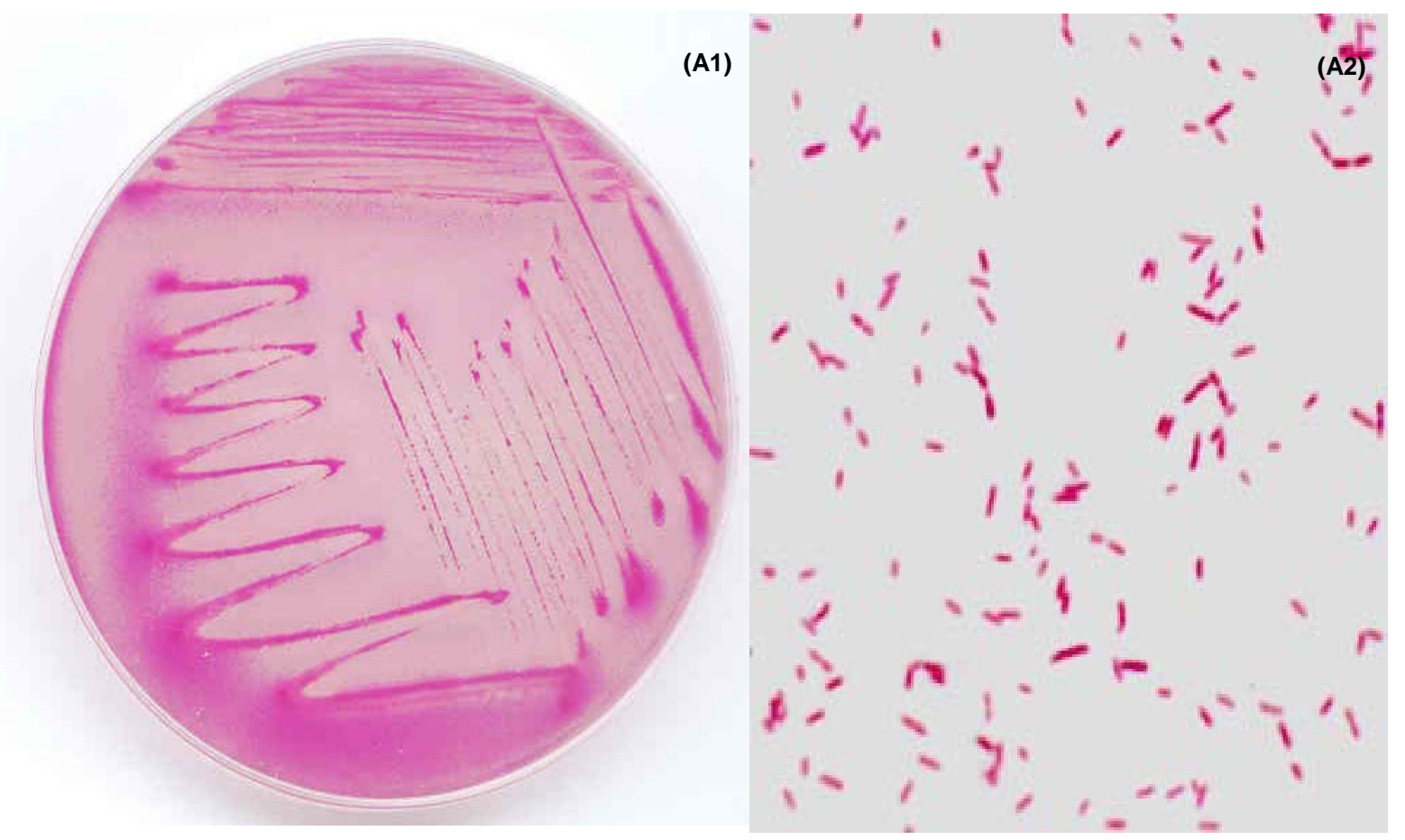

Figure 1. Culture of isolates on Mac Conkey media and microscopic observation after Gram staining (X 1000). (A1): Culture of isolates on MacConkey agar; (A2): Microscopic observation of cells shows Gram negative bacteria. 
(A) Experimental ARDRA profile

\section{Alul}

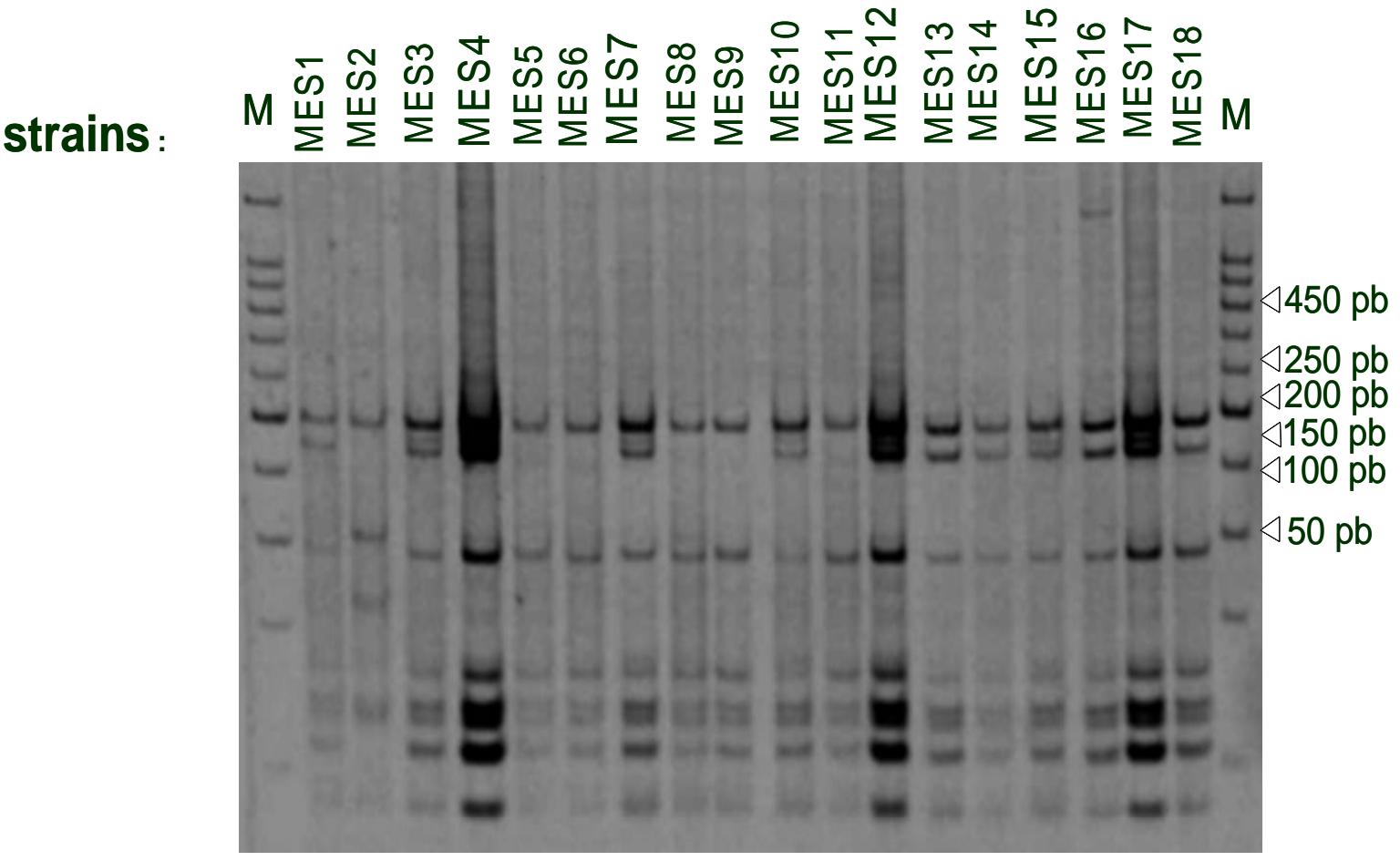

(B) Simulated ARDRA profile

123456758910

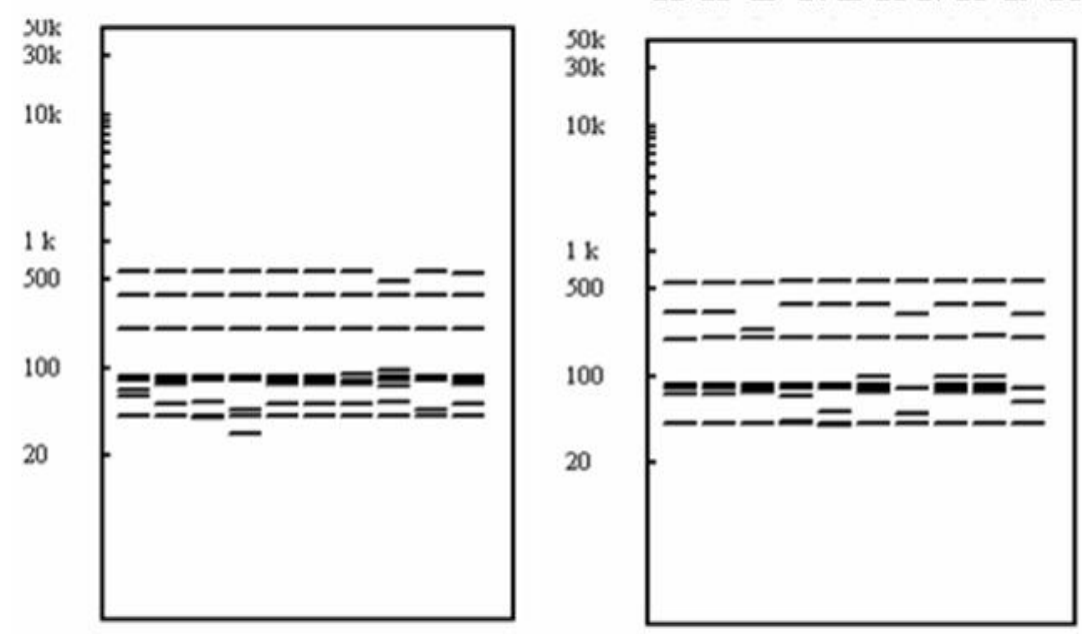

1- Klebsiella oxycota

2- Escherichia coli 3- Sabmonella enterica 4-Shigella dysenteriae 5-Yersinia pestis 6- Salmonella arizonae

7- Shigella flexneri

8- Shigella boydii 9-Escherichia fergusonii 10-Yersinia aldowa 11- Salmonella sakamue 12-Enterobacter alerogenes 13-Yersinia frederiksenii 14- Shigellk sonnei 15- Escherichia blattse 16-Enterobacter sakazaki 17- Sabnonella bongori 18-Yersinia kristensenii 19- Escherichia vuneris 20-Enterobacter cloucae

Figure 3. Experimental (A) and simulated (B) profile of 16S rDNA gene digested by the AluI enzyme and resolved on polyacrylamide gel. $M$ denote the 100 bp DNA ladder. 
DNAMAN (5.2.10 version) software was used to select restriction enzymes to generate restriction profiles after the simulation of ARDRA technique.

Using GenBank database a collection of $16 \mathrm{~s}$ rDNA sequence belonging to different genus of Enterobacteriacea family was generated. Then sequences obtained were digested using restriction enzymes for the simulation of the Restriction Fragment Length Polymorphism technique. This simulation was made by the software DNAMAN. At first these sequences were amplified and saved in the database software, thereafter we simulated the restriction of all these sequences by the restriction enzymes contained in the database software Restrict.enz (180 enzymes), in order to select the more discriminative restriction enzymes.

\section{Gel pro}

Band profiles of electrophoresis gels were analyzed using Gel pro software (for Windows, N/T version 3.1, 95). MVSP software was used to estimate levels of similarity between strains based on ARDRA profiles (version 3.13I, Kovach, on 1995).

All bands acquired by the three restriction enzymes (theoretical and experimental bands) were treated by Gel - pro software to generate a matrix containing binary data. The clustering of strains was performed according to the Unweighted Pair Group Method with Arithmatic Mean method using MVSP software.

\section{Results and discussion}

On the basis of morphological criteria, 47 isolates were selected from 10 meat samples from different environmental origins (Table 1). Strains were predominantly isolated from the samples of meat of fowl and sheep. The microscopic observation shows that all isolates were Gram-negative bacilli (Figure 1).

Morphological identification showed a higher proportion of strains of Yersinia, Enterobacter and Salmonella spp. This result agrees with studies of Michael et al. (1981) which focused on the biochemical identification of a collection of 2.200 isolates belonging to the family Enterobacteriacea isolated from various meat samples were phylogenetically closely related. Results showed that AluI, MspI and RsaI are the more discriminative restriction enzymes. After restriction of amplified DNA by selected endonucleases, the fragments generated are separated by size in an electrophoresis gel (Figure 3b, $4 b$ and $5 b)$. Based on their ARDRA profiles a dendrogramme exhibiting 12 groups with 47 strains was obtained (Figure 5). 
(A) Experimental ARDRA profile

\section{Rsal}

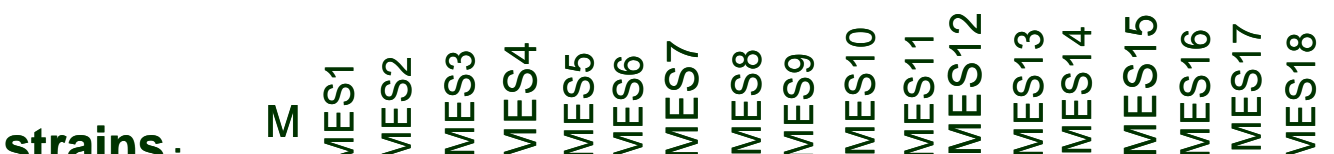

strains :

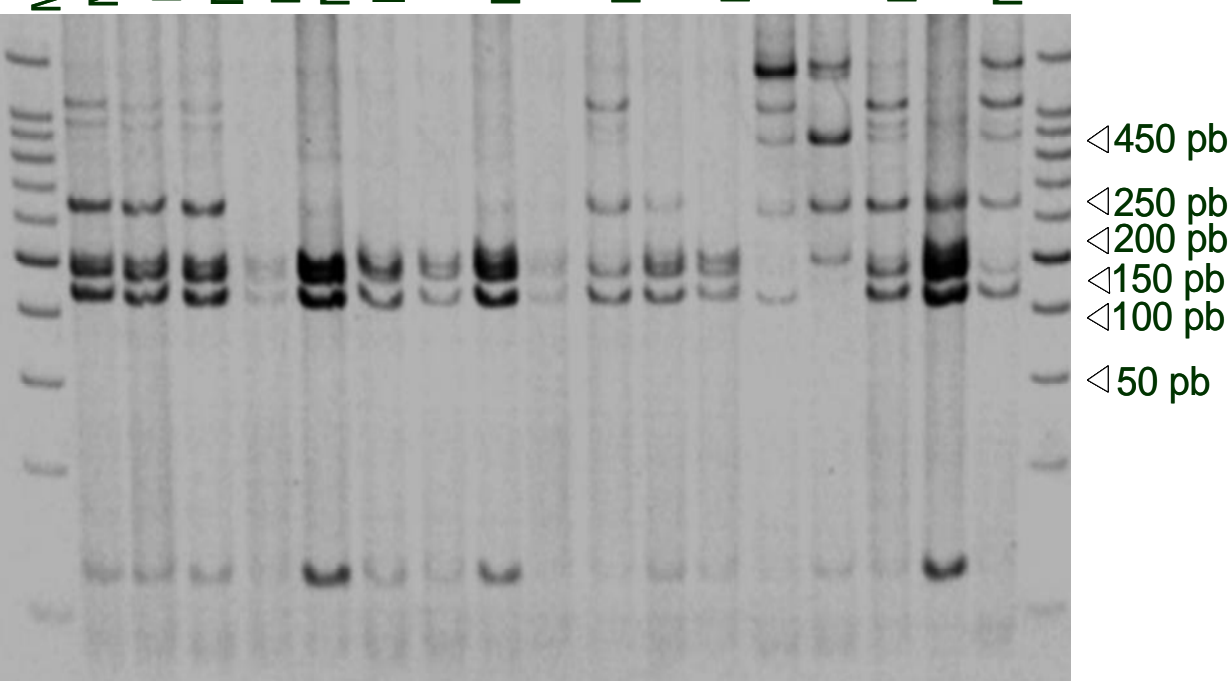

(B) Simulated ARDRA profile

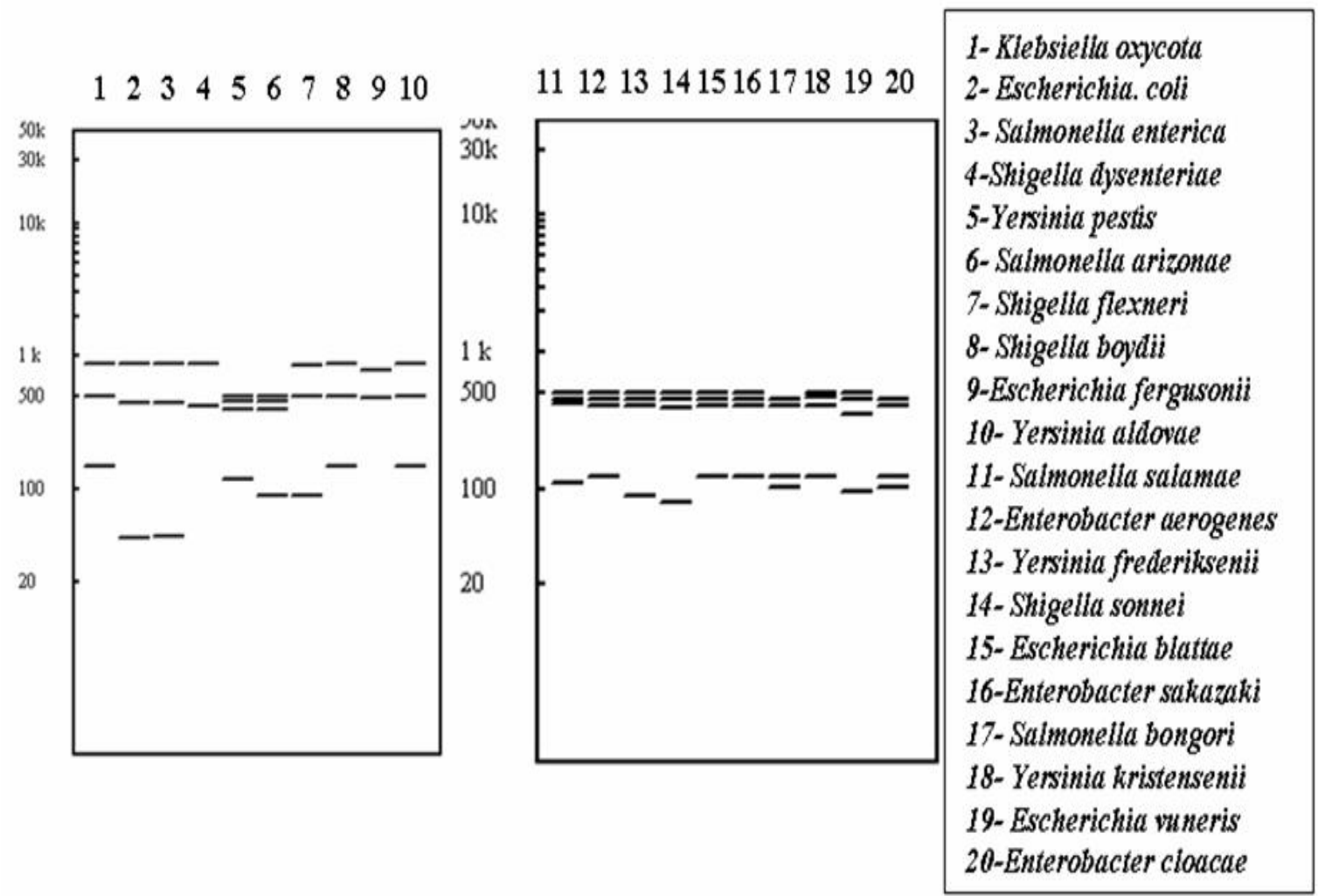

Figure 4. Experimental (A) and simulated (B) profile of 16S rDNA gene digested by the RsaI enzyme and resolved on polyacrylamide gel. $M$ denote the $100 \mathrm{bp}$ DNA ladder. 
(A) Experimental ARDRA profile

Mspl

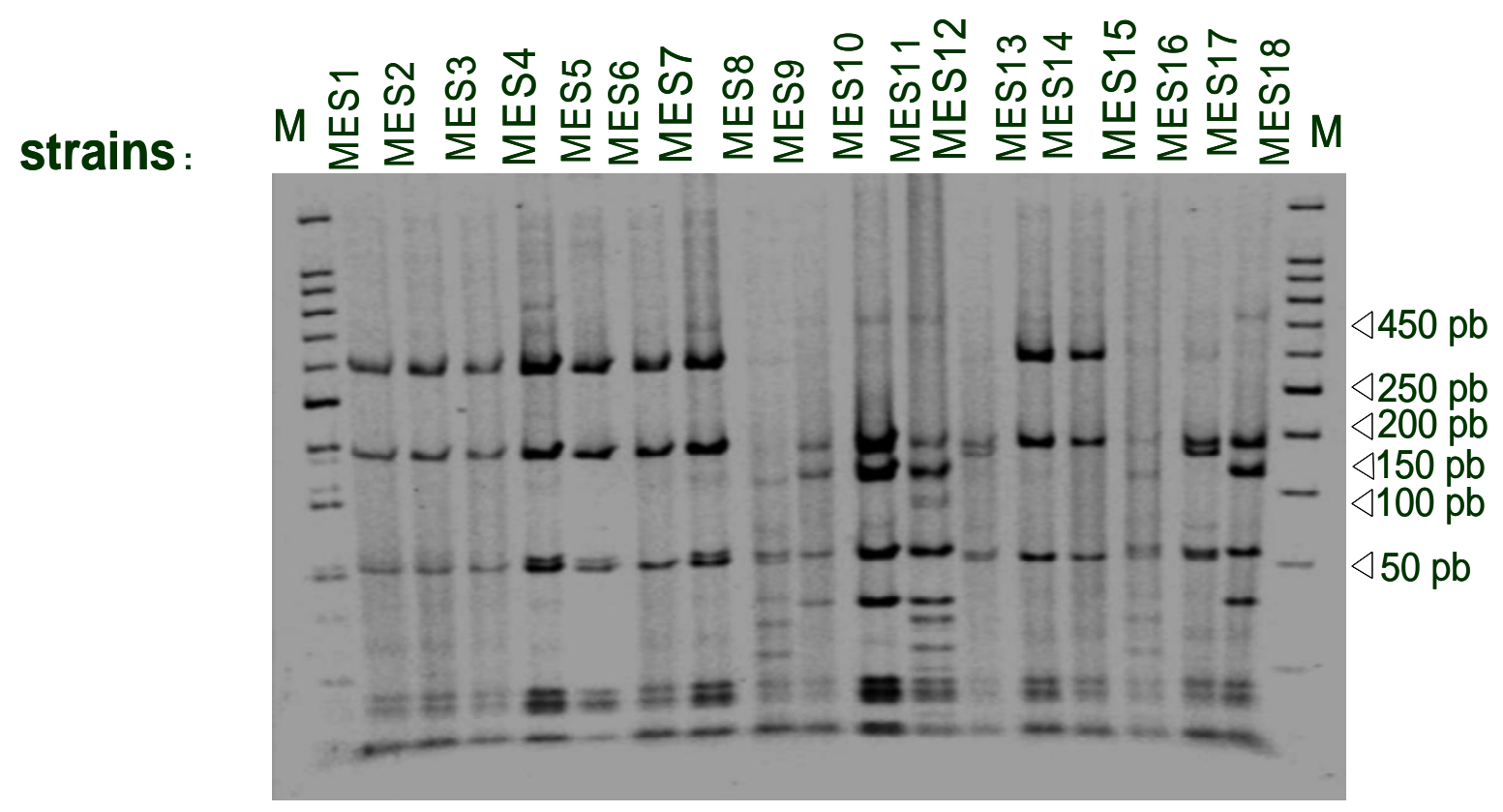

(B) Simulated ARDRA profile

$\begin{array}{llllllllll}12 & 3 & 4 & 5 & 6 & 7 & 8 & 9 & 10\end{array}$

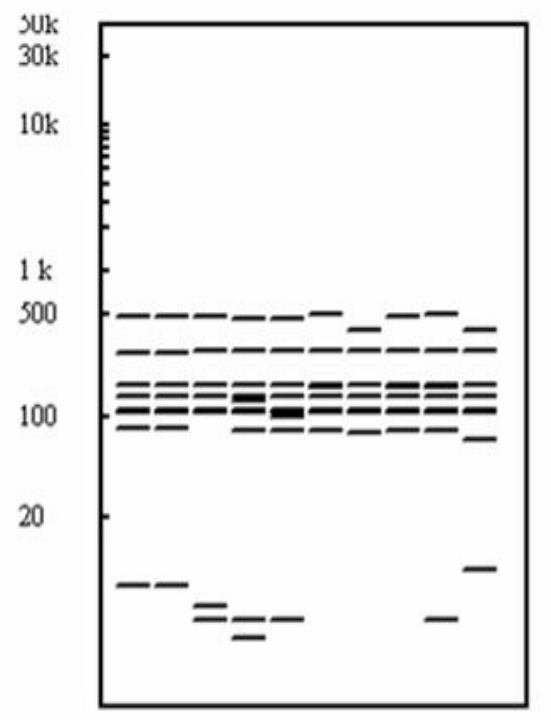

11121314151617181920

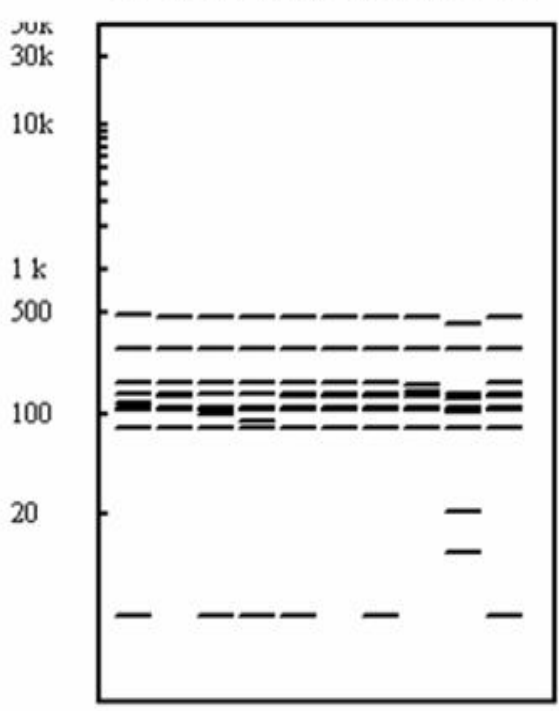

1- Escherichia vuneris

2- Escherichia. coli

3-Salmonella enterica

4-Shigella dysenteriae

5-Yersinia pestis

6- Salmonella arizonae

7- Shigella flexneri

8- Shigella boydii

9- Escherichia fergusonii

10- Yersinia aldovae

11- Salmonella salamae

12-Enterobacter aerogenes

13-Yersinia frederiksenii

14- Shigella sonnei

15- Escherichia blattue

16-Enterobacter sakazaki

17- Salmonella bongori

18- Yersinia kristensenii

19- Klebsiella oxycota

20-Enterobacter cloacae

Figure 5. Experimental (A) and simulated (B) profile of 16S rDNA gene digested by the MspI enzyme and resolved on polyacrylamide gel. $M$ denote the $100 \mathrm{bp}$ DNA ladder. 


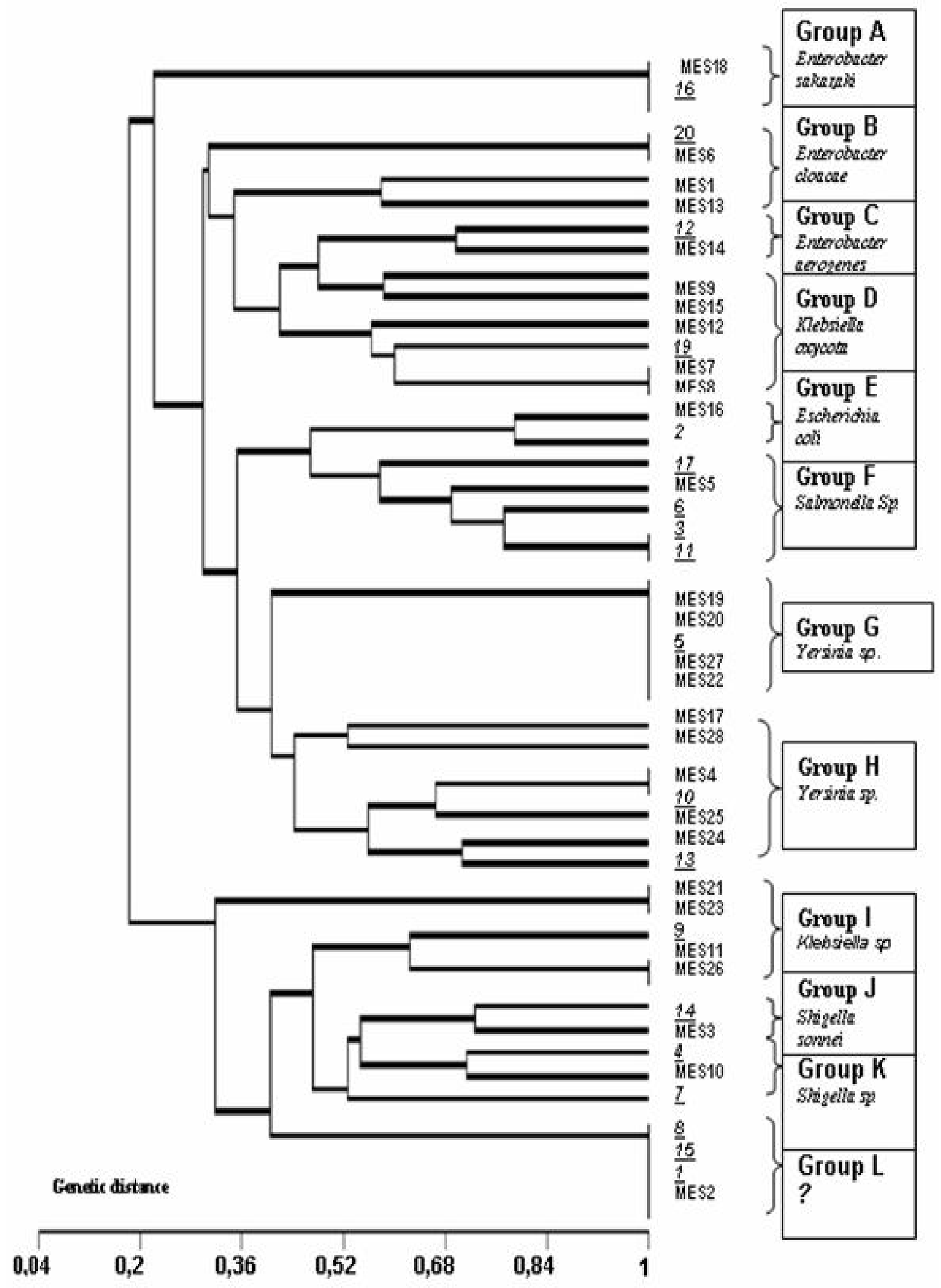

Figure 6. Dendrogramme of the percent genetic similarity estimated by comparison of experimental and theoretic ARDRA profiles.* Strains that begin with the prefix MES are strain test (experimental), strains with number are control strain (theoretical). 
Table (3) shows the abundance of Yersinia and Enterobacter genus, they represent respectively $25 \%$ and $17 \%$ of the isolated stocks, the rest is divided in Klebsiella oxytoca (6 strains), Escherichi coli (2 strains), Salmonella spp. (5 strains) and Klebsiella spp. (5 strains), Shigella sonnei (2 strains) and Salmonella spp.(3 strain).

Table 3. Identification of strains according to dendrogramme of Figure 5.

\begin{tabular}{|c|c|c|c|c|}
\hline $\begin{array}{l}\text { ARDRA } \\
\text { Group }\end{array}$ & $\begin{array}{l}\text { Number of } \\
\text { strains }\end{array}$ & Strains & Genus & Species \\
\hline A & 2 & MES18, 16 & Enterobacter & $\begin{array}{l}\text { Enterobacter } \\
\text { sakazaki }\end{array}$ \\
\hline B & 4 & MES6, MES1, MES13, 20 & Enterobacter & $\begin{array}{l}\text { Enterobacter } \\
\text { cloacae }\end{array}$ \\
\hline $\mathrm{C}$ & 2 & MES14, 12 & Enterobacter & $\begin{array}{l}\text { Enterobacter } \\
\text { aerogenes }\end{array}$ \\
\hline $\mathrm{D}$ & 6 & $\begin{array}{l}\text { MES9, MES15, MES12, MES7, } \\
\text { MES8, } 19\end{array}$ & Klebsiella & $\begin{array}{l}\text { Klebsiella } \\
\text { oxycota }\end{array}$ \\
\hline $\mathrm{E}$ & 2 & MES16, 2 & Escherichia & $\begin{array}{l}\text { Escherichia. } \\
\text { coli }\end{array}$ \\
\hline $\mathrm{F}$ & 5 & MES5, 2, 17, 6,3,11 & Salmonella & $s p$. \\
\hline G & 5 & MES19, MES20, MES27,MES22, 5 & Yersinia & $s p$. \\
\hline $\mathrm{H}$ & 7 & $\begin{array}{l}\text { MES17, MES28, MES4, MES25 } \\
\text { MES24, 10, } 13\end{array}$ & Yersinia & $s p$. \\
\hline I & 5 & MES21, MES23, MES11, MES26, 9 & Klebsiella & $s p$. \\
\hline $\mathrm{J}$ & 2 & MES3, 14 & Shigella & $\begin{array}{l}\text { Shigella } \\
\text { sonnei }\end{array}$ \\
\hline $\mathrm{K}$ & 3 & MES10, 7, 4 & Shigella & $s p$. \\
\hline $\mathrm{L}$ & 4 & MES2, $4,8,15$ & ? & ? \\
\hline
\end{tabular}

\section{Conclusion}

Bacterial identification using molecular tools constitute an essential complement to classical methods, which are mainly based on morphological and biochemical analyses. The most efficient approach is $16 \mathrm{~S}$ rDNA sequencing and the comparison to type strain sequences available in public databases. In order to optimize the cost and time necessary to identify different genus and species of the Enterobacteriaceae family, we performed the In silico-ARDRA (amplified rDNA restriction analysis) a new method for the identification of strains isolated from environmental origins.

\section{References}

Birnboim, H. and J. Doly. 1979. A rapid alkaline extraction procedure for screening recombinant plasmid DNA. Nucleic Acids Res. 7:1513-1523.

Brenner. 1980. Bergey's Manual of Systematic Bacteriology. 
Chen, W. and T. Kuo. 1993. A simple and rapid method for the preparation of Gram negative bacterial genomic DNA. Nucleic Acids Res. 21:2260-2265.

Dennis, A. B., K. Ilene, J. L. David, O. James and L. W. David. 2008. GenBank. Nucleic Acids Res. 36:25-30.

Drancourt, M., C. Bollet, A. Carlioz,, R. Martelin, J. P. Gayral and D. Raoult. 2000. 16S ribosomal DNA sequence analysis of a large collection of environmental and clinical unidentifiable bacterial isolates. J. Clin. Microbiol. 38:3623-30.

Ewing, W. H., J. J. Farmer and D. J. Brenner. 1980. Proposal of Enterobacteriaceae fam. nov., nom. rev. to replace Enterobacteriaceae Rahn 1937, nom. fam. cons. (Opin. 15, Jud. Comm. 1958), which lost standing in nomenclature on 1 January 1980. Int. J. Syst. Bacteriol. 30:674-675.

Hormaeche, E. and P. R. Edwards. 1960. A proposed genus Enterobacter. Internat. Bull. Bacteriol. Nomenclature Taxon. 10:71-74.

Heyndrickx, M., K. Vandemeulebroecke, B. Hoste, P. Janssen, K. Kersters and P. deVos. 1996. Reclassification of Paenibacillus (formerly Bacillus) pulvifaciens (Nakamura 1984). Int. J. Syst. Bacteriol. 46:270-9.

Le Minor 1986. Genus Salmonella, Lignières 1900. In Bergey's Manual of Systematic Bacteriology, edited by Sneath P.H.A. and al. Edition: Williams and Wiikins Baltimore. London. Los Angeles. Sydney. 427-458.

O'Hara, C. M. and J. M. Miller. 2003. Evaluation of the Vitek 2 IDGNB Assay for Identification of Members of the Family Enterobacteriaceae and Other Nonenteric Gram-Negative Bacilli and
Comparison with the Vitek GNICard. J. Clin. Microbiol. 41:2096-101.

Messaoudi, A., M. Gtari, A. Bdabbous and F. Wagenlehner. 2009. Identification and susceptibility of Klebsiella and Enterobacter spp. isolated from meat products. Afr. J. Microbiol. 3:362-369.

Michael, E., S. Stiles and N. Lai-king. 1981. Biochemical characteristics and identification of Enterobacteriaceae isolated from meats. Appl. Environ. Microbiol. 50:639-645.

Michel, D., B. Claude, C. Antoine, M. Rolland, G. Jean-Pierre and R. Didier. 2000. 16S Ribosomal DNA Sequence Analysis of a Large Collection of Environmental and Clinical Unidentifiable Bacterial Isolates. J. Clin. Microbiol. 38:3623-3630.

Nataro, J. P. and J. B. Kaper, 1998. Diarrheagenic Escherchia coli. Clin. J. Rev.11:142-201.

Jensen, M., J. Webster and N. Straus. 1993. Rapid identification of bacteria on the basis of polymerase chain reactionamplified ribosomal DNA spacer polymorphisms. Appl. Environ. Microbiol. 59:945-952.

Williams. 1965. Bergey's Manual of Systematic Bacteriology.

Wheeler, A., D. Oerther, N. Larsen, D. Stahl and L. Raskin. 1996. The oligonucleotide probe database. Appl. Environ. Microbiol. 62:3557- 3559. 